EWA Trojnar

Uniwersytet Jagielloński

\title{
DROGA KOBIET DO POLITYKI NA TAJWANIE W KONTEKŚCIE WYBORÓW POWSZECHNYCH W 2016 ROKU
}

\section{Wprowadzenie}

Wybory prezydenckie na Tajwanie w 2016 roku wygrała Tsai Ing-wen*, tym samym po raz pierwszy w dziejach Republiki Chińskiej najwyższe stanowisko państwowe objęła kobieta. Nominacja ta mogłaby zostać uznana za ewenement w tajwańskiej polityce, co zresztą niezwłocznie nagłaśniały światowe media ${ }^{1}$, gdyby wziąć pod uwagę jedynie chińską tradycję,

* Do zapisów wyrazów w języku chińskim zastosowano alfabet fonetyczny hanyu pinyin bez znaków tonalnych. Wyjątkiem od tej reguły są imiona Tajwańczyków zapisane zgodnie z wolą autorów czy postaci, a więc w przyjętej przez nich transkrypcji, często Wade'a-Gilesa lub innej utrwalonej, pochodzącej z języków lokalnych. Nazwiska Chińczyków i Tajwańczyków stawia się tradycyjnie przed imieniem i tę zasadę utrzymano zarówno w tekście, jak i w przypisach, z wyjątkiem sytuacji, w której sami autorzy praktykują odmienną formę zapisu lub przyjmują zachodnie imiona, wtedy zastosowano inicjał imienia i nazwisko.

${ }^{1}$ Por. B. Bland, Tsai Ing-wen wins Taiwan's presidential election, „Financial Times”, 16 I 2016, www.ft.com/content/b1375b14-bc45-11e5-846f-79b0e3d20eaf (5.02.2017); A. Ramzy, Tsai Ing-wen Elected President of Taiwan, First Woman to Hold Office, „New York Times”, 16 I 2016, www.nytimes.com/2016/01/17/world/asia/taiwan-elections.html?_r=0 (5.02.2017); C. Sui, Taiwan's first female leader, shy but steely Tsai Ing-wen, BBC, 17 I 2016, www.bbc.com/news/world-asia-35320444 (6.02.2017); C. Campbell, Taiwan Elects Its First Female President, „The Time”, 16 I 2016, http:// 
współtworzącą tożsamość kulturową mieszkańców Tajwanu, której ważnym elementem pozostaje patriarchalizm. Tymczasem warto spojrzeć na wybory polityczne dokonywane przez Tajwańczyków z nieco innej perspektywy i odnieść je do przemian, jakich mieszkańcy Tajwanu doświadczyli w ostatnich dekadach, oraz sytuacji politycznej poprzedzającej elekcję w 2016 roku. Na tej podstawie można założyć, że rosnący udział kobiet w życiu politycznym na Tajwanie towarzyszy demokratyzacji.

W pracy zwraca się uwagę na ewolucję uregulowań prawnych dotyczących praw politycznych kobiet na Tajwanie, starając się zaprezentować najważniejsze stadia ich wdrażania. $Z$ tego powodu badanie poprzedza wprowadzenie dotyczące tradycji chińskiej, w której próżno szukać tego typu wzorców, następnie kształtowania się zjawiska w Chinach w pierwszej połowie XX wieku, a więc w warunkach tworzenia Republiki Chińskiej po upadku cesarstwa oraz jej kontynuacji na Tajwanie w latach 1945-1990. Ocenie skuteczności podjętych przez demokratyzujące się państwo działań służy zbadanie zmiany pozycji kobiet w polityce w latach 1991-2016. Przyjęte cezury ostatnich dwudziestu pięciu lat określają: pierwsza - symboliczny początek procesu demokratyzacji, kiedy przyjęto pierwsze poprawki do konstytucji, a druga - ostatnie wybory prezydenckie i parlamentarne, w których triumfowała Tsai Ing-wen i kierowana przez nią Demokratyczna Partia Postępowa (Democratic Progressive

time.com/4183442/china-taiwan-tsai-ing-wen-first-female-president/ (5.02.2017); T. Philips, Taiwan elects first female president, „The Guardian”, 16 I 2016, www.theguardian.com/world/2016/jan/16/taiwan-elects-first-female-president (5.02.2017); Taiwan election: Tsai Ing-wen is Taiwan's first female president after landslide victory in historic poll, "South China Morning Post”, 16 I 2016, www.scmp.com/news/china/ policies-politics/article/1901800/taiwan-election-tsai-ing-wen-taiwans-first-female (5.02.2017); Tsai Ing-wen wins Taiwan leadership election, Xinhua, 16 I 2016, http:// news.xinhuanet.com/english/2016-01/16/c_135016019.htm (5.02.2017); Taiwan election: First female president Tsai Ing-wen elected after landslide victory against ruling Kuomintang, www.abc.net.au/news/2016-01-16/taiwan-elects-first-female-presidenttsai-ing-wen/7093338 (5.02.2017); Taiwan elects its first female president: Tsai Ing-wen, Kyodo, AFP-Jiji, „Japan Times”, 16 I 2016, www.japantimes.co.jp/news/2016/01/17/ asia-pacific/politics-diplomacy-asia-pacific/taiwan-elects-first-female-president-tsaiing-wen/\#.WJdum9LhDZ4 (5.02.2017). 
Party, DPP), pozostawiając w pokonanym polu politycznych rywali z Partii Narodowej (Kuomintang, KMT).

\section{Dziedzictwo tradycji}

Tradycyjnie w Chinach wizerunek kobiety definiował żeński symbol yin, którego dopełnienie stanowił męskim symbol yang. Ich wzajemne uzupełnianie się, zbudowane na zasadzie przeciwności (ciemny - jasny, słaby - silny itp.), stanowiło sens całego istnienia. Tylko mężczyzna z kobietą stanowili jedność. Rolę kobiet definiowała także tradycja $r u$, której najbardziej rozpoznawalnym przedstawicielem był Konfucjusz (551-479 p.n.e.), rozprzestrzeniająca się w początkach naszej ery. Zakładała ona istnienie ściśle określonych zależności w społeczeństwie: pomiędzy władcą a poddanym, ojcem a synem, mężem i żoną, pomiędzy braćmi oraz pomiędzy przyjaciółmi. W obrębie panującej hierarchii każdą jednostkę zobowiązywano do przestrzegania określonych zasad moralnych, przypisując im szeroki katalog powinności i obowiązków w stosunku do innych. Dużą wage przywiązywano do relacji w rodzinie - zadaniem kobiety było w niej zajmowanie się domem i rodziną męża, do której wchodziła automatycznie poprzez zamążpójście. Wiele czynności sfery religijnej i symbolicznej było przypisane jedynie mężczyznom, jak choćby odprawianie obrzędów związanych z kultem zmarłych przodków, którzy otaczali opieką żyjących na ziemi potomków. Taki układ sytuował kobietę w roli podrzędnej w stosunku do mężczyzny. W świetle tradycji konfucjańskiej rolę kobiety charakteryzowały lojalność, posłuszeństwo i oddanie. W okresie feudalnym wielożeństwo było warunkowane możliwościami fizycznego utrzymania żon przez męża ${ }^{2}$.

${ }^{2}$ Szerzej zob. Yao Xinzhong, Konfucjanizm. Wprowadzenie, tłum. J. Hunia, Kraków 2009; Rozważania (Dialogi konfucjańskie), oprac. Uczniowie Konfucjusza, tłum. J. Zawadzki, Seattle 2012; Nowe „Dialogi konfucjańskie”: próba rekonstrukcji, oprac. Qian Ning, tłum. S. Musielak, Ożarów Mazowiecki 2014. 
W dziejach Państwa Środka warto przywołać także te kobiety, które wychodziły jednak poza tradycyjnie przypisane im role i wpływały na losy kraju, pełniąc ważne funkcje polityczne i religijne. Przykładów nie znajdziemy jednak wiele: cesarzowa wdowa Lu (241-180 p.n.e.) w czasach Wcześniejszej Dynastii Han czy cesarzowa wdowa Cixi (1835-1908) z dynastii Qing. To właśnie one po śmierci swoich mężów sprawowały faktyczną władzę w państwie. Rządziły jednak tylko jako regentki w imieniu małoletnich cesarzy - Lu w latach 195-180 p.n.e., a Cixi w latach 1861-1908 i formalnie nie przysługiwał im tytuł cesarza. Najbardziej jaskrawym przykładem wyjścia poza tradycyjne pojmowanie sytuacji kobiety w Chinach była postać Wu Zetian (624-705) w czasach dynastii Tang, jedynej w historii Chin kobiety cesarza. Wu Zetian, uzyskawszy ten tytuł w 690 roku, rządziła przez 15 lat aż do śmierci³.

Podwaliny pod zmianę zasad traktowania kobiet w społeczeństwie chińskim wnieśli Tajpingowie - członkowie wcześniej utworzonego tajnego Stowarzyszenia Wielbicieli Boga, którzy doprowadzili do wielkiego antyrządowego powstania chłopskiego na terenie Chin (1850-1864). Przyjęte przez nich rozwiązania miały rewolucyjny charakter także dla losów kobiet. W ogłoszonej w 1853 roku tzw. ustawie ziemskiej znalazł się zapis mówiący o równouprawnieniu płci. Przydział ziemi miał być dokonywany w równych proporcjach pomiędzy mężczyzn i kobiety. Jednocześnie zakazywano krępowania stóp kobietom oraz umożliwiono im służbę w armii

\section{Dziedzictwo Republiki Chińskiej na kontynencie}

Już na początku XX wieku chińskie sufrażystki w ramach ruchu prorepublikańskiego aktywnie uczestniczyły w działaniach na rzecz obalenia

${ }^{3}$ Biografie cesarzowych szerzej zob. J. Clements, Wu. Chińska cesarzowa, tłum. M. Szubert, Warszawa 2009; J. Chang, Cesarzowa wdowa Cixi. Konkubina, która stworzyła współczesne Chiny, tłum. A. Grelak, Kraków 2015.

${ }^{4}$ H.B. Rhee, Asian Millenarianism: An Interdisciplinary Study of the Taiping and Tonghak Rebellions in a Global Context, Youngstown-New York 2007, s. 237. 
cesarstwa. Ich zaangażowanie w Lidze Związkowej, powstałej w 1905 roku, wynikało z akceptacji zasady równości mężczyzn i kobiet, do której odwoływała się ta organizacja i jej przewodniczący Sun Yat-sen (1966-1925)5. Próżno jednak w jego autorskiej myśli politycznej szukać choćby deklaracji o potrzebie zmiany pozycji społecznej i politycznej kobiet w Chinach. Postulowane przez niego tzw. trzy zasady ludu - narodowa, władzy ludu i jego dobrobytu - dotyczyły raczej równości, a nie równouprawnienia ${ }^{6}$.

Gdy 1 stycznia 1912 roku proklamowano powstanie Republiki Chińskiej, przyjmowane kolejno ustawy zasadnicze, obowiązujące w latach 1912-1928, nie zagwarantowały jednak praw wyborczych kobietom. Kiedy te nie skapitulowały, protestując przeciw nielojalności polityków, ich sytuacja zdecydowanie się pogorszyła. W 1913 roku działalność zrzeszającej ich interesy organizacji walczącej o prawa wyborcze dla kobiet została wręcz zakazana ${ }^{7}$. Kwestia praw politycznych dla kobiet była drugoplanowa, szczególnie że czasom młodej republiki towarzyszył raczej wszechogarniający chaos wynikający z brutalnej walki o władzę․ Niezdolność polityków głównego nurtu do szybkiego i trwałego zjednoczenia Chin i wprowadzenia rządów prawa9 starały się wykorzystać także chińskie sufrażystki do realizacji własnych celów. Ruch kobiecy odżył ze wzmożoną siłą w latach dwudziestych XX wieku. Sprzyjał mu duch przemian i modernizacji. Przykładowo studencki Ruch Czwartego Maja 1919 roku, który wybuchł w Pekinie jako sprzeciw wobec postanowień konferencji paryskiej, kończącej I wojnę światową, rozlał się na inne chińskie miasta i wykroczył poza cele

${ }^{5}$ Li Yu-ning, Sun Yat-sen and Women's Transformation, „Chinese Studies in History" 1988, 21, 4, s. 62.

${ }^{6}$ Sun Yat-sen, Trzy zasady ludu, tłum. A. Łobacz, Warszawa 2014.

${ }^{7}$ L. Edwards, Women's Suffrage in China: Challenging Scholarly Conventions, "Pacific Historical Review” 2000, 69, 4 (Woman Suffrage: The View from the Pacific), s. 621-662.

${ }^{8}$ Szerzej zob. Ł. Gacek, Chińskie elity polityczne w XX wieku, Kraków 2009, s. $47-55$.

${ }^{9}$ Przed pierwszymi wyborami doszło do zjednoczenia Ligi Związkowej i kilku mniejszych partii prorewolucyjnych, a 25 sierpnia 1912 roku w Pekinie powołano Partię Narodową, której przewodniczącym został Sun Yat-sen. 
polityczne likwidacji specjalnych przywilejów, jakie mocarstwa chciały utrzymać w Chinach. Ruch ten pobudził społeczeństwo do refleksji nad wieloma zjawiskami kulturowymi, w tym do dyskusji na temat równości płci, pracy i wyzwolenia kobiet w zakresie ich udziału w życiu politycznym, dostępie do edukacji, dążeniach do rozwoju kariery. Ocenia się, że początkowo postulaty te miały jedynie propagandowy charakter ${ }^{10}$. Niemniej jednak już na początku lat dwudziestych w Pekinie powołano do życia organizacje promujące prawa polityczne kobiet. Działalność aktywistek nie ograniczała się jedynie do stolicy. W tamtym czasie ich sukcesy można było mierzyć osiągnięciami w Hunanie, Guangdongu, Zhejiangu i Sichuanie, gdzie zrównano prawa polityczne mężczyzn i kobiet ${ }^{11}$. Osiągnięcia te wpisywały się w procesy modernizacji, które przechodziły republikańskie Chiny przełomu wieków ${ }^{12}$. Ponad wszelką wątpliwość przemianom sprzyjał postęp technologiczny i infrastrukturalny. Troska władzy o edukację kobiet i zapewnienie możliwości jej zdobywania zarówno w Chinach, jak i poza granicami była dla niej nowym wyzwaniem. Dopiero w 1928 roku wydano pierwsze przekrojowe opracowanie naukowe Historii kobiet $w$ Chinach (Zhongguo funushi), której autorem był Chen Dongyuan z Uniwersytetu Pekińskiego, uczeń Hu Shi, filozofa z tej uczelni i aktywisty powiązanego z Ruchem Nowej Kultury ${ }^{13}$.

W podzielonych ideologicznie Chinach władze obydwu partii - zarówno Kuomintangu (KMT), jak i Komunistycznej Partii Chin (KPCh) ${ }^{14}-$

${ }^{10}$ Szerzej zob. Li Changli, The Social Consequences of the May Fourth Movement: The Establishment of Women's Property Rights, "Chinese Studies in History” 2010, 43, 4, s. 20-42.

${ }^{11}$ L. Edwards, Women's Suffrage in China..., s. 623.

${ }^{12}$ Prawa polityczne dla kobiet były jednym z wielu postulatów chińskich feministek tamtych czasów, obok wolnego wyboru partnera i zawierania małżeństwa, zdobywania wykształcenia, a także zakazu krępowania stóp. Zob. A. Zemanek, Córki Chin i obywatelki świata. Obraz kobiety w chińskich czasopismach o modzie, Kraków 2013, s. 60.

${ }^{13}$ Q.E. Wang, Women's History in China: Editor's Introduction, „Chinese Studies in History" 2012, 45, 4, s. 3.

${ }^{14}$ Komunistyczna Partia Chin została powołana 1 lipca 1921 roku w Szanghaju, a na jej pierwszego przewodniczącego wybrano Chen Duxiu. 
wykorzystywały aktywizujące się kręgi feministek do własnych celów politycznych. W kręgach elit politycznych wyjątkową rolę mogły odgrywać jedynie wybitne lub zasłużone działaczki, bądź te lepiej uprzywilejowane ze względu na wpływy rodzinne lub finansowe. Obydwie partie powołały wzorowane na rozwiązaniach sowieckich urzędy do spraw kobiet (Żenotdieł). KPCh opierała się na działalności ruchu związkowego robotnic fabrycznych, które jednoczono wokół idei wolnościowych w życiu zawodowym, społecznym oraz politycznym i na których barkach miała spoczywać współodpowiedzialność za sukces socjalistycznej rewolucji. Działalność ruchu kobiet pod egidą KMT ograniczała się do żądań równouprawnienia w sferze społecznej. Na etapie względnej współpracy pomiędzy nacjonalistami i komunistami (1923-1927) działalność ruchów feministycznych odnosiła największe sukcesy na polu edukacji kobiet na temat przysługujących im praw. Jednak już w czasie ekspedycji północnej Kuomintang dokonywał masowych rzezi kobiet podejrzewanych o sprzyjanie komunistom ${ }^{15}$.

Pozycja kobiet w kręgach komunistycznych była naturalnie znacznie silniejsza niż w łonie Kuomintangu. Zmianom w sferze obyczajowej towarzyszyło uznanie robotnic w fabrykach i kobiet wiejskich za aktywnych uczestników rewolucji - wstępowały one do Komunistycznej Partii Chin i zasilały szeregi wojskowe. W przyjętej w 1931 roku konstytucji Chińskiej Republiki Sowieckiej - republiki, która istniała w latach 1931-1937 na obszarze prowincji Jiangxi - znalazły się między innymi gwarancje emancypacji kobiet oraz ich uczestnictwa w życiu społecznym, gospodarczym, politycznym i kulturalnym (art. 11) $)^{16}$.

Zmiany praw politycznych dla kobiet w Chinach nie przyniosło też ani zjednoczenie państwa pod wodzą Chiang Kai-sheka w 1928 roku, ani przyjęcie tymczasowej konstytucji przez rząd narodowy 21 maja 1931 roku. Niemniej jednak warto odnotować, że ta ustawa zasadnicza zrównywała

${ }^{15}$ M. French, From Eve to Dawn. A History of Women in the World, t. 4: Revolutions and Struggles for Justice in $20^{\text {th }}$ Century, New York 2008, s. 92-119; K.A. Johnson, Women, the Family, and Peasant Revolution in China, Chicago 1983, s. 39-50.

${ }^{16}$ The Legal System of the Chinese Soviet Republic 1931-1934, ed. W.E. Butler, New York 1983. 
wszystkich obywateli wobec prawa bez względu na płeć, religię, pochodzenie rasowe czy kastowe (art. 6), a także wskazywała na potrzebę wyrównania szans edukacyjnych pomiędzy płciami (art. 48). Było to ważnym zalążkiem tworzenia nowego państwa, choć wciąż odbiegało od zachodnich wzorców demokracji, do których chciały nawiązywać chińskie elity ${ }^{17}$. Za rządów Kuomintangu wprowadzono kilka regulacji prawnych wynikających z przyjętej konstytucji i wspierających pozycję kobiety w społeczeństwie. W 1928 roku formalnie ustanowiono jednożeństwo i zakazano poligamii. Usankcjonowano jednak konkubinat i tu zasady monogamii już nie obowiązywały $^{18}$. W 1931 roku zaczął obowiązywać nowy kodeks cywil$n y^{19}$. Pozycję kobiet w Chinach osłabiła antynomia konkurencyjnych porządków politycznych i ideologicznych. Kuomintang w swojej walce z komunizmem odwołał się do tradycyjnych chińskich wartości, które wraz z elementami chrześcijaństwa i nacjonalizmu stały się podstawą kampanii społecznej Ruch Nowego Życia, zapoczątkowanej w 1934 roku $^{20}$.

W latach trzydziestych organizacje feministyczne kontynuowały działalność na rzecz udziału kobiet w polityce. Postulowały o wprowadzenie regulacji prawnych w wyborze delegatów do Zgromadzenia Narodowego w sposób powszechny, równy i bezpośredni. Gdy powstał projekt nowej konstytucji w 1936 roku, jej przyjęcie pokrzyżowała japońska inwazja w Chinach w 1937 roku $^{21}$.

Dopiero w czasie wojny domowej pomiędzy narodowcami a komunistami (1945-1949) wprowadzono prawa wyborcze dla kobiet na poziomie ogólnopaństwowym. Konstytucja, opracowana już w 1936 roku, została przyjęta przez Zgromadzenia Narodowe 25 grudnia 1946 roku w Nankinie,

${ }^{17}$ A. Teon, Provisional Constitution Of The Republic Of China (1931), „The Greater China Journal", 31.05.2016, https://china-journal.org/2016/05/31/provisionalconstitution-of-the-republic-of-china-1931/ (2.01.2016).

${ }^{18}$ Ł. Gacek, Chińskie elity..., s. 116.

${ }^{19}$ Li Changli, The Social Consequences..., s. 28-29.

${ }^{20}$ J. Fenby, Czang Kaj-szek i jego Chiny, tłum. J. Włodarczyk, Wrocław-Poznań 2010, s. 280.

${ }^{21}$ L. Edwards, Women's Suffrage in China..., s. 625-626; China's struggle for constitutionalism, „The Round Table” 1945, 35, 140, s. 340-344. 
promulgowana przez rząd 1 stycznia 1947 roku, a zaczęła obowiązywać 25 grudnia 1947 roku. Ustawa ta zagwarantowała równość wobec prawa bez względu na płeć, wyznanie, pochodzenie etniczne, klasowe i przynależność partyjną (art. 7) 22. Dodatkowo zobowiązywała państwo do roztoczenia specjalnej ochrony nad kobietami i dziećmi, zatrudnionymi do prac fizycznych, adekwatnie do ich wieku i kondycji fizycznej (art. 153) ${ }^{23}$. W konstytucji ujęto również zapis o konieczności prowadzenia w państwie działań mających na celu ochronę macierzyństwa i promocję dobrostanu kobiet i dzieci, jako fundamentów bytu i rozwoju narodu (art. 156) ${ }^{24}$. Osobno wskazano też równość względem prawa do edukacji (art. 159) ${ }^{25}$. W zakresie przestrzegania praw wyborczych kobiet konstytucja zagwarantowała miejsca w Zgromadzeniu Narodowym, będącym naczelnym organem „władzy politycznej” w zamyśle ojca założyciela republiki Sun Yat-sena ${ }^{26}$, delegatom wybranym przez organizacje kobiece (art. 26 pkt. 7) ${ }^{27}$. Wskazywała również na konieczność opracowania odrębnych regulacji prawnych gwarantujących liczbę mandatów dla kobiet w Yuanie Ustawodawczym w ramach grup: przedstawicieli Mongolii, Tybetu, mniejszości etnicznych na obszarach przygranicznych, obywateli Chin mieszkających zagranicą i organizacji zawodowych (art. 64) ${ }^{28}$. Odrębny artykuł konstytucji gwarantował opracowanie uregulowań prawnych co do kwot dla kobiet ubiegających się o stanowiska pochodzące $\mathrm{z}$ wyborów (art. 134) ${ }^{29}$. Ustalono je na poziomie $10 \%^{30}$.

${ }^{22}$ The Constitution of the Republic of China, Taiwan Documents Project, www. taiwandocuments.org/constitution01.htm (2.02.2017).

${ }^{23}$ Ibidem.

${ }^{24}$ Ibidem.

${ }^{25}$ Ibidem.

${ }^{26}$ J. Rowiński, W. Jakóbiec, System konstytucyjny i przedstawicielski Tajwanu, Warszawa 2015, s. 73.

${ }^{27}$ The Constitution of the Republic of China...

${ }^{28}$ Ibidem.

${ }^{29}$ Ibidem.

${ }^{30}$ L. Edwards, Women's Suffrage in China..., s. 626. 
Warto w tym miejscu dodać, że prawna sytuacja kobiet w Chinach poprawiła się po powstaniu w 1949 roku Chińskiej Republiki Ludowej, która zrównała w prawach mężczyznę i kobietę. Zamknięto domy publiczne, a prostytutki zaczęto przyuczać do zawodu w zakładach wychowawczych przez kilka następnych lat. Pomagano im znaleźć pracę lub wyjść za mąż.

\section{Dziedzictwo Republiki Chińskiej na Tajwanie}

Wyspiarskie położenie Tajwanu nie uchroniło go od wpływów modernizacji. Przykładowo w powstałej 1887 roku średniej szkole dla dziewcząt warunkiem przyjęcia było przestrzeganie zakazu krępowania stóp. W okresie japońskiej kolonizacji Tajwanu (1895-1945) ukonstytuowały się pierwsze organizacje feministyczne, które kształtowały dyskurs wolnościowy i postulaty związane z płcią kulturowo-społeczną.

Po kapitulacji Japonii w 1945 roku władze wojskowe Republiki Chińskiej przejęły kontrolę nad Tajwanem. Nieufność mieszkańców do nowych namiestników wynikająca z grabieżczej i brutalnej polityki tych drugich doprowadziła do włączenia Tajwanu 20 maja 1949 roku do obszarów na kontynencie, na których obowiązywał już od grudnia 1948 roku stan wojenny. Wprowadzały go doraźne przepisy do konstytucji, przyjęte przez Zgromadzenie Narodowe 18 kwietnia 1948 roku w Nankinie - „Tymczasowe przepisy na czas mobilizacji w celu stłumienia rebelii”. Na ich podstawie cała władza mogła pozostać w rękach prezydenta w czasie zagrożenia ze strony komunistów, a stanowisko to sprawował wówczas generalissimus Chiang Kai-shek. W wyniku poniesionej klęski w wojnie domowej narodowców z komunistami w 1949 roku na Tajwan wraz z Chiang Kai-shekiem ewaluowało się nawet ok. dwóch milionów wojskowych, urzędników i ich rodzin. W 1950 roku objął on ponownie najwyższy urząd w państwie, który sprawował aż do śmierci w 1975 roku.

Prowincja Tajwan ze stolicą w Tajpej stała się bastionem KMT i miejscem, gdzie odtwarzano zręby państwowości Republiki Chińskiej. Względy bezpieczeństwa i plany odzyskania kontynentu z rąk komunistów 
roztaczane przez władze kuomintangowskie przesądziły o utrzymaniu stanu wojennego na Tajwanie, co dla ponad sześciu milionów mieszkających tam Tajwańczyków (benshengren) wiązało się z dalszymi wyrzeczeniami i ograniczeniem swobód obywatelskich, nie wspominając o ich dyskryminacji na rzecz i przez przybyszy z kontynentu (waishengren). Udział tych pierwszych w życiu politycznym był znacznie ograniczony. Wybory bezpośrednie zawężały się do poziomu lokalnego. Ale i na tych szczeblach stanowiska dla benshengrenów nie były oczywiste, w sytuacji gdy środki na kampanie pozostawały w rękach waishengrenów. Wyborów do władz centralnych albo nie prowadzono, albo jedynie wraz z upływem czasu uzupełniano składy w Zgromadzeniu Ogólnym (1969, 1972, 1980, 1986) i Yuanie Ustawodawczym ${ }^{31}(1969,1972,1975,1980,1983,1989)$. Miejsca odchodzących zajmowali nowi członkowie Partii Narodowej. Większość mandatów naturalnie i tak pozostawała w rękach kuomintangowskiej starszyzny, wybranej jeszcze w 1947 roku na kontynencie. W sytuacji zakazu funkcjonowania partii opozycyjnych wyłoniła się jednak nieznaczna liczba kandydatów niezależnych - wszyscy o tajwańskim pochodzeniu. Mówiono o nich tangwei - co można przetłumaczyć z chińskiego jako „spoza partii”, naturalnie spoza Kuomintangu. To właśnie oni tworzyli legalne podstawy dla ruchu opozycyjnego.

Głos opozycji nabierał na sile wraz z polityką opresyjnego autorytaryzmu. Nie bez przyczyny rządy Kuomintangu na Tajwanie przeszły do historii pod mianem „białego terroru”. Głównym celem czystek była walka z przejawami komunizmu, a liczba poszkodowanych była niewspółmiernie większa od skali zjawiska ${ }^{32}$. Represji nie uniknęły kobiety, szczególnie te działające w opozycji. Reżim, podsycany ideą zbrojnego powrotu na kontynent w celu obalenia komunistów, przewidział dla kobiet jedynie

${ }^{31}$ Yuan Ustawodawczy (Lifa Yuan), parlament - jedna z pięciu izb, organów władz centralnych Republiki Chińskiej, obok Yuanu Wykonawczego (Xingzheng Yuan), czyli rządu, Yuanu Sądowniczego (Sifa Yuan), Yuanu Kontrolnego (Jiancha Yuan) i Yuanu Egzaminacyjnego (Kaoshi Yuan). Szerzej zob. J. Rowiński, W. Jakóbiec, System konstytucyjny..., s. 99-123.

${ }^{32}$ Szerzej zob. E. Trojnar, Tajwan. Dylematy rozwoju, Kraków 2015, s. 78. 
drugoplanowe i pomocnicze role, co tłumaczyło ich nieobecność w życiu politycznym państwa i brak szans na zmiany w ich położeniu.

Partia dbała jednak o wizerunek, powołując do życia organizacje kobiece - jedne o elitarnym charakterze, inne o szerszym, bo otwartym na tworzącą się klasę średnią. Członkiniami były głównie panie wywodzące się z kręgów rządowych i wojskowych. Ich liderką pozostawała Song Meiling, żona prezydenta Chiang Kai-sheka. Organizacje mobilizowały kobiety do służby społecznej, pomocniczej w walce z komunizmem, dlatego podejmowały się takich działań, jak: szycie odzieży dla żołnierzy, zbiórki pieniędzy, ubrań i żywności na cele wojskowe, prowadzenie barów mlecznych dla potrzebujących dzieci, utrzymywanie szkół i sierocińców dla sierot z rodzin wojskowych ${ }^{33}$. Funkcjonowały także związki kobiet wspierające ich tradycyjne role jako matek, żon dbających o harmonię w rodzinach, co traktowano jako ważny element życia obywatelskiego. Inne organizacje kobiece promowały ich status społeczny, dobrobyt, troszczyły się o podniesienie świadomości zdrowotnej kobiet czy ich kształcenie. Wszystkie te czynności niezbicie przypominały kampanie społeczne w ramach Ruchu Nowego Życia prowadzone przez Kuomintang w latach trzydziestych na kontynencie ${ }^{34}$.

Nie wszystkie kobiety bezkrytycznie wstępowały w szeregi organizacji głównego nurtu. Antagonizm pomiędzy benshengrenami i weishengrenami pobudził wykształcone zagranicą Tajwanki do alternatywnej działalności, której początki należy datować na lata siedemdziesiąte. Kobiety tworzyły zaczątki opozycyjnych organizacji kobiecych, angażowały się w działalność wydawniczą, edukacyjną i propagandową ${ }^{35}$. Wyjątkową rolę odegrała Lu Hsiu-lien (Annette Lu), która rozwinęła w swoich publikacjach idee tzw. nowego feminizmu (xin nuxingzhuyi), inspirowanego drugą falą zachodniego feminizmu, a także założyła wydawnictwo (Pioneer

${ }^{33}$ N. Diamond, Women Under Kuomintang Rule: Variations on the Feminine Mystique, „Modern China” 1975, 1, 1, s. 15.

${ }^{34}$ Ibidem, s. $15-18$.

${ }^{35}$ Szerzej zob. D.T. Chang, Women's Movements in Twentieth-Century Taiwan, Urbana 2009. 
Publishing ${ }^{36}$. Lu swoją karierę poświęciła pracy na rzecz środowisk opozycyjnych. Za działalność wywrotową na rzecz niepodległości Tajwanu podżeganie do rebelii $\mathrm{w}$ ramach wystąpienia na antyrządowym wiecu w 1979 roku - odsiedziała w więzieniu pięć i pół z dwunastu lat wyroku, a w latach 2000-2008 sprawowała urząd wiceprezydenta republiki ${ }^{37}$. Wraz z Lu wyrok odsiadywała opozycjonistka Chen Chu, która w okresie demokratyzacji sięgnęła po wysokie stanowiska państwowe: kierowała ministerstwem pracy w latach 2000-2005, a od 2006 roku - miastem Kaohsiung jako jego burmistrz. Aresztowania opozycjonistek nie zniweczyły działalności zwolenniczek ruchu feministycznego, z inicjatywy których w 1982 roku założono nowe wydawnictwo (Awakening).

Ewolucja polityki wewnętrznej na Tajwanie nie byłaby możliwa bez reorientacji planów zjednoczenia Chin pod egidą Kuomintangu i przyjęcia adekwatnej polityki zagranicznej. Pomimo silnego sojuszu ze Stanami Zjednoczonymi w pierwszych dekadach zimnej wojny znaczenie Republiki Chińskiej na Tajwanie stopniowo spadało. Komunistyczna Partia Chin, której elity doprowadziły jeszcze 1 października 1949 roku do proklamowania Chińskiej Republiki Ludowej (ChRL), umocniła swoją pozycję na kontynencie i po wielu latach starań zdołała przekonać większość światowych mocarstw, że pozostaje jedynym legalnym reprezentantem Chin. Na zmianę tę przystało Zgromadzenie Ogólne Organizacji Narodów Zjednoczonych w 1971 roku. W kolejnym roku Stany Zjednoczone wraz z Chińską Republiką Ludową w tzw. komunikacie szanghajskim uznały istnienie tylko jednych Chin, których częścią jest Tajwan, a w 1979 roku USA nawiązały stosunki dyplomatyczne z ChRL, zrywając je tym samym

${ }^{36}$ G.B. Harden, Chang Chiung-Fang, Fashion and Freedom: A Textual Analysis of Chinese Women from 1911 to 2011, [w:] New Modern Chinese Women and Gender Politics: The Centennial of the End of the Qing Dynasty, ed. Chen Ya-chen, New York 2014, s. 45.

${ }^{37}$ Biografia polityczna Lu Hsiu-lien zob. Lu Hsiu-lien, Ashley Esarey, My Fight for a New Taiwan: One Woman's Journey from Prison to Power, Seattle 2014; D. Chang, Two Women, Two Visions of Nationhood for Taiwan: Madame Chiang Kai-shek and Hsiu-lien Annette Lu, „Asian Journal of Women's Studies” 2009, 15, 2, s. 7-32. 
z Republiką Chińską na Tajwanie. W nowej sytuacji międzynarodowej, w której znalazł się Tajwan, kiedy oddaliła się realna możliwość wyzwolenia przez Kuomintang Chin od komunizmu, elity zdawały sobie sprawę z tego, że autorytarny styl władzy Kuomintangu może nie gwarantować im przetrwania, nawet na Tajwanie. Po śmierci Chiang Kai-sheka w 1975 roku stery władzy przejął jego syn Chiang Ching-quo. Pod jego kierownictwem Tajwan doświadczył spektakularnych przemian gospodarczych i społecznych. W latach siedemdziesiątych mechanizmy, także polityczne, zostały poddane stopniowej i oddolnej modyfikacji poprzez otwarcie monopartyjnej dyktatury KMT na nowych członków o lokalnych, tajwańskich korzeniach i umożliwienie im awansu. Ten proces określano mianem „tajwanizacji”. W 1986 roku tangwei nielegalnie powołali do życia nową partię polityczną - Demokratyczną Partię Postępową. Jednak dopiero w 1987 roku zniesiono stan wojenny ustanowiony trzydzieści osiem lat wcześniej. 22 kwietnia 1991 roku Zgromadzenie Narodowe uchyliło „Tymczasowe przepisy...”. Przestały one obowiązywać już 1 maja tegoż roku, co ogłosił prezydent Lee Teng-hui - z pochodzenia rodowity Tajwańczyk, który wstąpiwszy do KMT w 1970 roku, po niespełna dwudziestu latach wspiął się na sam szczyt władzy ${ }^{38}$. Tymczasem w 1991 roku na obszarze Tajwanu zaczęła na nowo obowiązywać konstytucja z 1947 roku, zawieszona tymczasowymi uregulowaniami.

\section{Demokratyzacja rządów Kuomintangu na Tajwanie}

Na początku lat dziewięćdziesiątych XX wieku Tajwan wkroczył na drogę przemian demokratycznych. Uchylenie „Tymczasowych przepisów...” jedynie symbolicznie inicjowało ten proces. W jego dynamice szczególnego znaczenia nabrało dostosowanie konstytucji do nowych potrzeb i uwarunkowań, wszak ta obowiązująca została przygotowana w 1936 roku. 1 maja

\footnotetext{
${ }^{38}$ Shih-shan H. Tsai, Lee Teng-hui and Taiwan's quest for identity, New York 2005.
} 
1991 roku weszły w życie pierwsze poprawki do konstytucji, wprowadzone jako Dodatkowe Artykuły Konstytucji Republiki Chińskiej39. Uwzględniały one między innymi prawa polityczne kobiet poprzez zagwarantowanie 10\% mandatów dla nich we wszystkich trzech izbach: Zgromadzeniu Narodowym, Yuanie Ustawodawczym i Yuanie Kontrolnym. Wskazany udział opisywała procedura, według której dla kobiet zarezerwowano jeden mandat na nie mniej niż pięć i nie więcej niż dziesięć w każdej kategorii, z wyłączeniem miejsc dla aborygenów. Ponadto w przypadku gdy liczba zwycięskich mandatów przekroczy dziesięć, jedno miejsce na każde dodatkowe dziesięć gwarantowano kobietom ${ }^{40}$.

$\mathrm{Z}$ czasem regulacje w zakresie praw politycznych kobiet rozszerzono także na wybory samorządowe. W uchwalonym prawie o samorządach lokalnych w 1999 roku zwiększono liczbę miejsc zarezerwowanych dla kobiet do jednej czwartej w wyborach lokalnych zarówno na szczeblu miejskim, jak i powiatowym, a także gminnym ${ }^{41}$.

W 1997 roku Zgromadzenie Narodowe przyjęło poprawkę do konstytucji (czwarta poprawka) ${ }^{42}$. Wraz z rozszerzeniem liczby mandatów w Yuanie Ustawodawczym do 225, począwszy od IV kadencji (lata 1998-2001), wskazano cztery kategorie: 168 mandatów w ramach wyborów kandydatów w miastach wydzielonych, powiatach i miastach na prawach powiatów, po cztery mandaty dla ludności aborygeńskiej na nizinach i wyżynach, osiem dla Chińczyków mieszkających poza granicami,

${ }^{39}$ Additional Articles of the ROC Constitution, „Occasional Papers/Reprints Series in Contemporary Asian Studies" 1995, 115, 2, s. 52-59; First revision, Office of the President, Republic of China (Taiwan), http://english.president.gov.tw/Default. aspx?tabid=434\#03 (2.02.2017).

${ }^{40}$ Additional Articles of the ROC..., s. 52-59.

${ }^{41}$ Local Government Act, Ministry of the Interior, Republic of China (Taiwan), www.moi.gov.tw/english/english_news/news_detail.aspx?sn=276\&type_code= (2.02.2017).

${ }^{42}$ Second revision, Office of the President, Republic of China (Taiwan), http:// english.president.gov.tw/Default.aspx?tabid=1032 (2.02.2017); Additional Articles to the Constitution of the Republic of China (Sixth Revision, 2000), Taiwan Documents Project, www.taiwandocuments.org/constitution04.htm (2.02.2017). 
a czterdzieści jeden proporcjonalnie dla kandydatów z ogólnokrajowych list partyjnych. Dla kobiet zarezerwowano jeden mandat na nie mniej niż pięć i nie więcej niż dziesięć w każdej kategorii z wyłączeniem miejsc dla aborygenów. Ponadto, w przypadku gdy liczba zwycięskich mandatów przekroczyłaby dziesięć, jedno miejsce na każde dodatkowe dziesięć gwarantowano kobietom (art. 4) ${ }^{43}$.

Kolejna - tym razem doniosła - zmiana systemu wyborczego została przyjęta na początku nowego milenium. 23 sierpnia 2004 roku parlament przegłosował ją jako poprawkę do konstytucji (siódma poprawka) ${ }^{44}$. Wraz z jej wdrożeniem Tajwan odchodził od systemu głosowania nieprzechodniego w ramach okręgów wielomandatowych w stronę ordynacji mieszanej z dominującą rolą okręgów jednomandatowych. Wraz z VII kadencją Yuanu Ustawodawczego (lata 2008-2012) ograniczono też liczbę posłów z 225 do 113, z których siedemdziesięciu trzech miało być wyłanianych z wyborów większościowych w okręgach jednomandatowych tworzonych w miastach wydzielonych, powiatach i miastach na prawach powiatów, po trzy mandaty zarezerwowano dla ludności aborygeńskiej na nizinach i wyżynach, trzydzieści cztery miejsca obsadzane były proporcjonalnie przez kandydatów z list partyjnych, które uzyskały przynajmniej 5\% głosów, z tym, że przynajmniej połowę wybranych z każdej listy kandydatów muszą stanowić kobiety ${ }^{45}$. W 2007 roku przyjęto poprawki do ustawy o powoływaniu i odwoływaniu urzędników służby cywilnej. Doprecyzowano w nich zasady obsadzana stanowisk urzędników państwowych pochodzących z wyborów powszechnych wszystkich szczebli, tak aby wypełnić konstytucyjny obowiązek obsadzenia połowy miejsc z list partyjnych przez kobiety ${ }^{46}$.

\section{${ }^{43}$ Ibidem.}

${ }^{44}$ Seventh revision, Office of the President, Republic of China (Taiwan), http:// english.president.gov.tw/Default.aspx?tabid=1033 (2.02.2017).

${ }^{45}$ Ibidem.

${ }^{46}$ Civil Servants Election and Recall Act, 28.05.2014, Ministry of the Interior, Republic of China (Taiwan), www.moi.gov.tw/english/english_law/law_detail. aspx?sn=300 (2.02.2017). 
Jednocześnie obok znaczącej poprawy sytuacji wyborczej kobiet nie zabrakło miejsca dla realizacji prawnej postulatów poprawiających ich sytuację w przeróżnych innych obszarach życia, w których były dyskryminowane. Przede wszystkim w 1992 roku przyjęto drugą poprawkę do konstytucji, która zapewniała o trosce państwa o godność kobiet, ochronę ich bezpieczeństwa i eliminację dyskryminacji ze względu na płeć (art. 18) ${ }^{47}$. Wprowadzono ponadto przepisy: penalizujące prostytucję, zrównujące możliwości zatrudnienia, wprowadzające ubezpieczenie zdrowotne dla gospodyń domowych, gwarantujące subwencje dla kobiet ciężarnych i matek opiekujących się niemowlętami, piętnujące przemoc domową, zabezpieczające równość prawa do własności małżonków, przeciwdziałające molestowaniu seksualnemu, zapobiegające handlowi ludźmi i przestępstwom na tle seksualnym. Podobnie poprawiła się sytuacja prawna kobiet z dyskryminowanych we wcześniejszych latach mniejszości etnicznych, a także małżonek pochodzących z Chin kontynentalnych.

W 2007 roku na Tajwanie przyjęto tzw. międzynarodową kartę praw kobiet, czyli Konwencję w sprawie likwidacji wszelkich form dyskryminacji kobiet $^{48}$. Dokument ten definiował dyskryminację kobiet, którą odnoszono między innymi do braku poszanowania równości podstawowych wolności w życiu politycznym, a także wskazywał, że troska o ich przestrzeganie spoczywa na państwie (art. 1 i 3). W szczególności zaś podkreślał, że:

Państwa Strony podejmą wszelkie stosowne kroki, aby zlikwidować dyskryminację kobiet w życiu politycznym i publicznym państwa, a w szczególności aby zapewnić kobietom, na równych z mężczyznami warunkach, prawa: a) głosowania we wszystkich wyborach i referendach publicznych oraz wybieralności do wszelkich organów wybieranych powszechnie, b) uczestniczenia w kształtowaniu polityki Państwa i jej realizacji,

${ }^{47}$ Additional Articles of the ROC..., s. 60; Second revision.

${ }^{48}$ Konwencja została przyjęta 18 grudnia 1979 roku przez Zgromadzenie Ogólne ONZ, a weszła w życie 3 września 1981 roku. Convention on the Elimination of All Forms of Discrimination against Women, United Nations, www.un.org/womenwatch/ daw/cedaw/text/econvention.htm (2.02.2017). 
zajmowania stanowisk publicznych i wykonywania wszelkich funkcji publicznych na wszystkich szczeblach zarządzania, c) uczestniczenia w organizacjach pozarządowych i stowarzyszeniach zajmujących się sprawami publicznymi i politycznymi Państwa (art. 7) ${ }^{49}$.

W 2011 roku na Tajwanie ogłoszono wdrożenie postanowień konwencji wraz z koniecznością podjęcia niezbędnych środków prawnych i administracyjnych w celu wyeliminowania dyskryminacji ze względu na płeć.

W tym miejscu warto dodać, że w 1953 roku władze Republiki Chińskiej stały się stroną międzynarodowej Konwencji o prawach politycznych kobiet, uchwalonej przez Zgromadzenie Ogólne ONZ 31 marca 1953 $\mathrm{roku}^{50}$. W dokumencie podkreślono zasadność równości pomiędzy kobietami i mężczyznami, bez jakiejkolwiek dyskryminacji przy głosowaniach (art. 1) i kandydowaniu w wyborach do wszelkich publicznie obieralnych organów ustanowionych na mocy prawa (art. 2), a także uprawnione do piastowania urzędów publicznych i pełnienia wszelkich funkcji publicznych przewidzianych w ustawodawstwie krajowym (art. 3) ${ }^{51}$.

\section{Kobiety parlamentarzystki}

Tajwańska scena polityczna na przestrzeni ostatnich dwudziestu pięciu lat z wolna stała się także przestrzenią większej aktywności kobiet. Ich partycypacja w polityce nie jest już ewenementem, lecz faktem, który wpisał się w styl tamtejszej polityki. W IX Yuanie Ustawodawczym, którego kadencja przypada na lata 2016-2020, udział kobiet jest rekordowo wysoki - 38\%.

${ }^{49}$ Konwencja w sprawie likwidacji wszelkich form dyskryminacji kobiet, przyjęta przez Zgromadzenie Ogólne Narodów Zjednoczonych dnia 18 grudnia 1979 r., Dz.U. 1982, nr 10, poz. 71.

${ }^{50}$ Konwencja została uchwalona 31 marca 1953 roku przez Zgromadzenie Ogólnego ONZ, a weszła w życie 7 lipca 1954 roku. Convention on the Political Rights of Women, New York, 31 March 1953, https://treaties.un.org/pages/ViewDetails. aspx?src=TREATY\&mtdsg_no=XVI-1\&chapter=16\&clang=_en\#2 (2.02.2017).

${ }^{51}$ Konwencja o prawach politycznych kobiet z dnia 31 marca 1953 r., Dz.U. 1955, nr 16, poz. 86 . 
W 1992 roku zaledwie 10\% miejsc w parlamencie obsadzały kobiety, na przełomie wieków utrzymały $20 \%$ miejsc, a od 2008 roku przekroczyły poziom $30 \%$. Ewolucyjny charakter zjawiska podsumowują dane zawarte w tabeli 1.

Tabela 1. Kobiety w parlamencie od II do IX kadencji Yuanu Ustawodawczego (1992-2020)

\begin{tabular}{|l|c|c|c|c|c|c|c|c|}
\hline & 1992 & 1995 & 1998 & 2001 & 2004 & 2008 & 2012 & 2016 \\
\hline $\begin{array}{l}\text { Liczba ko- } \\
\text { biet (okręgi } \\
\text { wyborcze) }\end{array}$ & 12 & 19 & 35 & 39 & 32 & 17 & 20 & 25 \\
\hline $\begin{array}{l}\text { Liczba kobiet } \\
\text { (listy partyjne) }\end{array}$ & 5 & 4 & 8 & 11 & 15 & 17 & 18 & 18 \\
\hline $\begin{array}{l}\text { Liczba wszyst- } \\
\text { kich wybra- } \\
\text { nych kobiet }\end{array}$ & 17 & 23 & 43 & 50 & 47 & 34 & 38 & 43 \\
\hline $\begin{array}{l}\text { Liczba miejsc } \\
\text { w parlamencie }\end{array}$ & 161 & 164 & 225 & 225 & 225 & 113 & 113 & 113 \\
\hline $\begin{array}{l}\text { Udział kobiet } \\
\text { w parlamencie }\end{array}$ & $10,6 \%$ & $14,0 \%$ & $19,1 \%$ & $22,2 \%$ & $20,9 \%$ & $30,1 \%$ & $33,6 \%$ & $38,1 \%$ \\
\hline
\end{tabular}

Źródło: opracowanie własne na podstawie: Legislators, Legislative Yuan, Republic of China (Taiwan), www.ly.gov.tw/en/03_leg/legList.action (2.02.2017); N. Batto, A victory for diversity, https://frozengarlic.wordpress.com/2016/01/17/a-victory-for-diversity/ (2.02.2017).

Nie ulega wątpliwości, że zwiększeniu udziału kobiet w legislatywie sprzyjała zmiana systemu wyborczego, gdyż od 2008 roku Tajwańczycy oddawali głosy w systemie mieszanym - zarówno w okręgach jednomandatowych (siedemdziesiąt trzy mandaty ze stu trzynastu), jak i proporcjonalnie $\mathrm{z}$ list partyjnych (trzydzieści cztery mandaty ze stu trzynastu), na których 50\% miejsc zarezerwowano dla kobiet. System ten nie ograniczył 
dominacji dwóch partii politycznych KMT i DPP, pomiędzy którymi podzieliła się większość mandatów. Niezależnie od tego szanse obsadzenia miejsc w parlamencie przez pozostałe, dotychczas mniejsze partie polityczne wiązały się z koniecznością przekroczenia pięcioprocentowego progu wyborczego. Wówczas partie te są również zobligowane zapewnić połowę miejsc kobietom. W efekcie tego posłanki reprezentują niemal wszystkie zwycięskie ugrupowania, co w odniesieniu do wyników wyborów z 2016 roku prezentuje tabela 2 .

Tabela 2. Kobiety w parlamencie według podziału partyjnego, IX kadencja Yuanu Ustawodawczego (2016-2020)

\begin{tabular}{|l|c|c|c|}
\hline & Liczba kobiet & Liczba mandatów & Udział kobiet \\
\hline DPP & 26 & 68 & $38 \%$ \\
\hline KMT & 12 & 35 & $34 \%$ \\
\hline NPP $^{52}$ & 2 & 5 & $40 \%$ \\
\hline QMD $^{53}$ & 2 & 3 & $66,(6) \%$ \\
\hline NPSU $^{54}$ & 1 & 1 & $100 \%$ \\
\hline Niezależni & 0 & 1 & 0 \\
\hline Razem & 43 & 113 & $38 \%$ \\
\hline
\end{tabular}

Źródło: opracowanie własne na podstawie: Legislators, Legislative Yuan, Republic of China (Taiwan) www.ly.gov.tw/en/03_leg/legList.action (2.02.2017).

Badacze tajwańskiej sceny politycznej podkreślają znaczenie ostatnich wyborów z 2016 roku w kontekście rosnącego udziału kobiet w polityce. Przykładowo Nathan Batto stwierdził, że kobiety „wygrywają realną władzę”, przy czym uzyskane przez nich „zyski są zrównoważone”,

\footnotetext{
${ }^{52}$ Partia Nowej Siły (Shadai Liliang; New Power Party, NPP).

${ }^{53}$ Partia Najpierw Naród (Qinmindang, QMD; People First Party, PFP).

${ }^{54}$ Związek Solidarności Bezpartyjnych (Wudang Tuanjie Lianmeng; Non-Partisan Solidarity Union, NPSU).
} 
a „społeczeństwo pluralistyczne" 55 . Umieścił on Tajwan w światowej czołówce państw przywiązujących dużą wagę do równości płci w polityce ${ }^{56}$. Punktami odniesienia były Norwegia i Niemcy, gdzie również rządzą kobiety. Według Batto zwycięstwo Tsai było godne uwagi również ze względu na fakt, że nie wywodziła się z rodziny polityków ${ }^{57}$.

Obserwatorzy wskazywali także, że w 2016 roku na tajwańskiej scenie politycznej dokonała się wymiana generacyjna. Gwenyth Wang zauważył, że czterdzieści trzy ze stu trzynastu mandatów, a więc 38\%, zostało obsadzonych przez polityków, którzy wcześniej ani nie zasiadali w parlamencie, ani nie sprawowali żadnej funkcji publicznej ${ }^{58}$. W innym zestawieniu Wang opisał tę zmianę poprzez wyliczenie sumarycznej liczby kadencji przepracowanych przez dziewiętnastu przegranych kandydatów z KMT, tj. sześćdziesiąt osiem, podczas gdy zastępujący ich posłowie z innych ugrupowań przepracowali w sumie jedynie sześć kadencji ${ }^{59}$. Konsekwentnie spadła też średnia wieku w gronie parlamentarzystów z pięćdziesięciu dwóch do pięćdziesięciu lat, a rekordowo stu jeden spośród stu trzynastu deputowanych miało poniżej czterdziestu lat. Najmłodsza w tym gronie Lu Sun-lin z DPP miała dwadzieścia osiem lat, gdy ubiegała się o elekcję. Wygrała ona w jednomandatowym okręgu wyborczym z Wu Yu-shengiem, pięćdziesięciosiedmioletnim doświadczonym politykiem i wieloletnim parlamentarzystą z ramienia $\mathrm{KMT}^{60}$. Uzupełniając tę obserwację, można stwierdzić, że pojawieniu się większej liczby młodych polityków czy wręcz osób niemających dotąd doświadczenia w tej profesji towarzyszył wzrost aktywności kobiet ${ }^{61}$.

${ }^{55}$ N. Batto, A victory for diversity, https://frozengarlic.wordpress.com/2016/ 01/17/a-victory-for-diversity/ (2.02.2017).

${ }^{56}$ Ibidem.

${ }^{57}$ Ibidem.

${ }^{58}$ G. Wang, A “Green” Legislature: Taiwan's New Parliament More Different Than Ever, Ketagalan Media, 17.02.2016, www.ketagalanmedia.com/2016/02/17/agreen-legislature-taiwan-new-parliament-more-different-than-ever/ (2.02.2017).

${ }^{59}$ Ibidem.

${ }^{60}$ Ibidem.

${ }^{61}$ Szerzej temat amatorów w tajwańskiej polityce w kontekście wyborów 2016 roku zob. A. Rudakowska, E. Trojnar, Who is a Political Newcomer? The Taiwanese Voters' Perspective, „Hemispheres. Studies on Cultures and Societies” 2016, 31, 3, s. 68-78. 
Niekwestionowanemu zwycięstwu kobiet w wyborach parlamentarnych nie towarzyszyły dalsze decyzje w tej izbie. Żadna z posłanek nie zajęła kierowniczej funkcji w Yuanie Ustawodawczym, co de facto można odczytać jako pogorszenie ich pozycji w porównaniu z poprzednimi kadencjami, do tego brak doświadczenia w polityce i kontaktów osłabia wizerunek kobiet w polityce. W efekcie tych wydarzeń działaczki organizacji feministycznych złożyły stosowne oświadczenia wzywające do zachowania równości płci w parlamencie ${ }^{62}$.

\section{Kobieta prezydent}

W państwach o kulturze konfucjańskiej kobiety sporadycznie sięgają po najwyższe stanowiska polityczne ${ }^{63}$. Spektakularne sukcesy kobiet w polityce oparte są najczęściej na koneksjach rodzinnych. Współcześnie tego typu odniesień można szukać w Birmie (Mjanmie) i Korei Południowej,

${ }^{62}$ Petycję poparły następujące organizacje feministyczne: Awakening Foundation, Taiwanese Feminist Scholars Association, National Alliance of Taiwan Women's Associations, Taipei Awakening Association, Kaohsiung Women Awakening Association, Garden of Hope Foundation, Taipei Women's Rescue Foundation. Odrębnym tematem, który warto rozwinąć w osobnej pracy, jest działalność tego typu organizacji feministycznych i ich zaangażowanie w polityce. Szerzej zob. $\mathrm{N}$. Hsieh, Women's rights groups call for election of a female speaker or deputy speaker, „The China Post”, 27.01.2016, www.chinapost.com.tw/taiwan/national/national-news/2016/01/27/457130/Womens-rights.htm (8.02.2017).

${ }^{63}$ Warto zaznaczyć, że bezprecedensowym wydarzeniem w dziejach Wietnamu był wybór 31 marca 2016 roku Nguyen Thi Kim Ngan na przewodniczącą Zgromadzenia Narodowego, jednego z najważniejszych organów władzy w tym państwie. Pani Nguyen była wiceprzewodniczącą legislatywy podczas wcześniejszej kadencji. W 1981 roku wstąpiła do Komunistycznej Partii Wietnamu, a od 2013 roku była członkinią Biura Politycznego KPW. Lokalny oddział magazynu „Forbes” ogłosił ją najbardziej wpływową Wietnamką 2016 roku. Wietnam. Kobieta po raz pierwszy na czele parlamentu, dt, PAP, wyborcza.pl, 31.03.2016, http://wyborcza. $\mathrm{pl} / 1,75399,19842167$,wietnam-kobieta-po-raz-pierwszy-na-czele-parlamentu.html (12.02.2017); Forbes list of 20 Most Influential Women in Vietnam, VietNamNet Bridge, 9.03.2016, http://english.vietnamnet.vn/fms/society/152249/forbes-list-of-20most-influential-women-in-vietnam.html (12.02.2017). 
a historycznie - w Indiach, Indonezji, na Sri Lance i Filipinach. W Birmie opozycjonistka i laureatka pokojowej Nagrody Nobla z 1991 roku Aung San Suu Kii, córka generała Aung Sana, premiera Birmy w latach 1946-1947, po odwilży politycznej w 2013 roku współuczestniczy w rządzeniu państwem i koncentruje władzę we własnych rękach, stojąc na stanowiskach szefowej dyplomacji, biura prezydenta, a także radcy stanu. W Korei Południowej Park Geun-hye, córka generała Parka Chung-hee, prezydenta w latach 1963-1979, sprawowała najwyższy rząd w państwie w latach 2013-2016. Jedyna kobieta premier w dziejach Indii - Indira Gandhi - sprawująca swój urząd w latach 1966-1977 i 1980-1984, była córką Jawaharlala Nehru, pierwszego premiera tego państwa w latach 1947-1964. Na sąsiedniej wyspie Cejlon Chandrika Bandaranaike Kumaratunga, kobieta prezydent Sri Lanki w latach 1994-2005, była córką małżeństwa premierów: Solomona Bandaranaike, który sprawował ten urząd w latach 1956-1960, i Sirimavo Bandaranaike, kobiety premier w latach 1960-1964, 1970-1977 i 1994-2000. Prezydentem Indonezji w latach 2001-2004 była Megawati Sukarnoputri, córka pierwszego prezydenta Indonezji w latach 1945-1967, Sukarno. Wreszcie osobnym przykładem pozostają Filipiny, gdzie Corazon Aquino była pierwszą kobietą prezydentem w dziejach Azji w latach 1986-1992, i choć stanowisko wygrała jako antagonistka reżimu prezydenta Ferdinanda Marcosa, to jednak nosiła nazwisko męża, senatora Benigno Aquino, zamordowanego wcześniej opozycjonisty. Kobietą prezydentem Filipin w latach 2001-2010 była także Gloria Macapagal-Arroyo, której ojciec Diosdado Macapagal sprawował tę funkcję w latach 1961-1965.

O zależnościach rodzinnych w polityce nie można mówić w przypadku prezydent Tsai Ing-wen, której ojciec był przedsiębiorcą budowlanym o wykształceniu mechanika samochodowego, a matka zajmowała się wychowywaniem dzieci. Zwycięstwo w wyborach prezydenckich zawdzięcza przede wszystkim własnej pracy, która ma raczej niewiele wspólnego z kulturą płci w polityce na tajwańskiej scenie politycznej. Prezydent Tsai ukończyła studia prawnicze w 1978 roku na National Taiwan University w Tajpej, dwa lata później uzyskała magisterium w Cornell University w Ithace, a 1984 roku obroniła doktorat w London School of Economics. Po powrocie 
do Tajwanu kontynuowała pracę akademicką, jednocześnie angażując się politycznie, początkowo $\mathrm{w}$ administracji prezydenta Lee Teng-huia, w zespole ekspertów zajmujących się tzw. teorią dwóch państw chińskich ${ }^{64}$ oraz przygotowaniami akcesyjnymi Tajwanu do Światowej Organizacji Handlu ${ }^{65}$, później w administracji prezydenta Chen Shui-biana (2000-2008). Wtedy to stanęła na czele Rady do spraw Kontynentu (Mainland Affairs Council, 2006-2008) i była wicepremierem rządu (2006-2008). Karierę polityczną w Demokratycznej Partii Postępowej zrobiła równie szybko i brawurowo - w 2008 roku wybrano ją na przewodniczącą partii zaledwie po czterech latach od wstąpienia $\mathrm{w}$ jej szeregi ${ }^{66}$. Z konkurentami politycznymi z Kuomintangu przegrała dwa razy: w 2010 roku stanowisko burmistrza Nowego Tajpej z Ericem Chu Li-lun (udział głosów: 47,39 do 52,61\%), a w 2012 roku prezydenta Republiki z ubiegającym się o reelekcję Ma Ying-jeou (udział głosów: 45,63 do 51,6\%). Przegraną tę należy wyjaśnić splotem uwarunkowań politycznych, w szczególności rywalizacji pomiędzy dwoma ugrupowaniami - KMT i DPP. Innymi słowy decyzje osobowe co do wyboru poszczególnych kandydatów miały mniejsze znaczenie. Przegrana Tsai Ing-wen wskazywała na względną słabość Demokratycznej Partii Postępowej w konfrontacji z osiągnięciami partii rządzącej, jaką był wówczas Kuomintang. Jednocześnie znów nie miała wiele wspólnego z niską pozycją kobiet w polityce na Tajwanie.

Wizerunek Tsai Ing-wen - kandydatki na stanowisko prezydenta: singielki, miłośniczki kotów, której najbliższą rodzinę stanowiły dwa z nich o imionach Myśl-Myśl (Xiang-Xiang) i Talent (Ah-Tsai) - silnie kontrastował z dotychczasowym obrazem polityka: heteroseksualnego mężczyzny oddanego rodzinie męża i ojca. Wizerunek ten sprzyjał też ostrej krytyce nie tylko osoby Tsai Ing-wen, ale i innych kandydatek, niezależnie od

${ }^{64}$ Taiwan's first woman president: 10 things you should know about Tsai Ing-wen, „Strait Times”, 20 V 2016, www.straitstimes.com/asia/east-asia/taiwans-firstwoman-president-10-things-you-should-know-about-tsai-ing-wen (12.02.2017).

${ }^{65}$ Chiński Tajpej został przyjęty do Światowej Organizacji Handlu w 2002 roku.

${ }^{66}$ K. Pletcher, Tsai Ing-wen, President of Taiwan, [hasło w:] Encyclopcedia Britannica, www.britannica.com/biography/Tsai-Ing-wen (23.01.2017). 
politycznej afiliacji, szczególnie że na etapie przygotowań do kampanii wyborczej tracący poparcie polityczne Kuomintang wystawił na stanowisko prezydenta szefową partii - Hung Hsiu-Chu. Co ciekawe, ataki o charakterze seksistowskim celowały raczej w kandydatki DPP niż KMT. Brian Hioe wyjaśnia to różnicami pomiędzy partiami, gdyż w generalnie zdominowanym przez mężczyzn świecie polityki to KMT znany był z uprzedzeń dla homoseksualizmu ${ }^{67}$. Tymczasem niezłomna postawa kandydatek DPP sprzyjała debacie na temat uznania małżeństwa tych samych płci, związków partnerskich i małżeństw wieloosobowych, co jednocześnie wzbogacało program polityczny DPP o nowe tendencje społeczne, odrzucane przez konserwatystów, a trafiające do młodych wyborców. Warto jednak podkreślić, że trzon programu politycznego Tsai Ing-wen nie odnosił się do tych kwestii, dotyczył reform w pięciu obszarach: sprawiedliwość pokoleniowa, instytucje rządowe, legislatywa, sprawiedliwość dziejowa i klimat polityczny ${ }^{68}$. W trakcie kampanii prezydenckiej przekonywała, że realizacja powziętych zamiarów ubiegania się i sprawowania najwyższego stanowiska w państwie jest właśnie jej szczególnym obowiązkiem w imię troski o równość kobiet i mężczyzn ${ }^{69}$.

Interesującą kwestią dotyczącą obserwowanego poszerzenia udziału kobiet w polityce na Tajwanie stały się, zasygnalizowane wyżej, decyzje wewnątrzpartyjne co do zgłaszanych kandydatur. O ile w wyborach prezydenckich 2012 roku jedyną z nich była Tsai Ing-wen, o tyle cztery lata później już w każdej parze wystąpiła kobieta. Jedynie z ramienia DPP od razu i niezmiennie to kobieta ubiegała się o główne stanowisko. Podczas kampanii poprzedzającej wybory KMT pierwotnie wyłonił szefową partii Hung

${ }^{67} \mathrm{~B}$. Hioe, Tsai Ing-Wen, Hung Hsiu-Chu, and the Confucian discourse of the family and the state in Taiwan, New Bloom, 10.7.2015, https://newbloommag. net/2015/10/07/tsai-hung-soong-confucian-family/ (12.02.2017).

${ }^{68}$ Tsai Ing-wen's Five Major Reforms, Light up Taiwan, 16.8.2015, http://iing.tw/ en/21 (12.02.2017).

${ }^{69}$ Chen Wei-han, Elections: Tsai repeats call for her followers not to split votes, „Taipei Times”, 13.01.2017, www.taipeitimes.com/News/taiwan/archives/2016/01/ $13 / 2003637101(6.02 .2017)$. 
Hsiu-chu na konkurentkę Tsai Ing-wen. Jednak na trzy miesiące przed wyborami, decyzją większości członków, wymienił ją Eric Chu - burmistrz Nowego Tajpej - co jednak i tak nie doprowadziło tej partii do zwycięstwa. Nie pozostawia cienia wątpliwości, że decyzje wystawienia kandydatur kobiet w wyborach prezydenckich były skalkulowane politycznie i spełniały potrzeby wyborców co do akceptacji równouprawnienia. Wyniki wyborów w 2012 i 2014 roku zostały zestawione w tabeli 3, nazwiska kandydatek oznaczono wytłuczonym drukiem.

Tabela 3. Porównanie wyborów prezydenckich i wiceprezydenckich w 2012 i 2016 roku

\begin{tabular}{|l|c|l|c|}
\hline \multicolumn{2}{|c|}{2012} & \multicolumn{2}{c|}{2016} \\
\hline \multicolumn{1}{|c|}{ Kandydaci } & Wyniki & \multicolumn{1}{c|}{ Kandydaci } & Wyniki \\
\hline $\begin{array}{l}\text { Ma Ying-jeou (KMT) } \\
\text { Wu Den-yih (KMT) }\end{array}$ & $51,60 \%$ & $\begin{array}{l}\text { Eric Chu (KMT) } \\
\text { Wang Ju-hsuan (niezależna) }\end{array}$ & $31 \%$ \\
\hline $\begin{array}{l}\text { Tsai Ing-wen (DPP) } \\
\text { Su Jia-chyuan (DPP) }\end{array}$ & $45,63 \%$ & $\begin{array}{l}\text { Tsai Ing-wen (DPP) } \\
\text { Chen Chien-jen (niezależny) }\end{array}$ & $56,1 \%$ \\
\hline $\begin{array}{l}\text { James Song (PFP) } \\
\text { Lin Ruey-shiung (PFP) }\end{array}$ & $2,77 \%$ & $\begin{array}{l}\text { James Song (PFP) } \\
\text { Hsu Hsin-ying (MKT) }\end{array}$ & $12,8 \%$ \\
\hline
\end{tabular}

Źródło: Presidential Elections, Central Election Commission, Republic of China (Taiwan), www.cec.gov.tw/english/cms/pe (6.02.2017).

Sukces wyborczy Tsai Ing-wen należy wiązać przede wszystkim ze zwycięstwem Demokratycznej Partii Postępowej jako partii opozycyjnej, które wynikało ze spadku zaufania Tajwańczyków do władzy Kuomintangu po 2008 roku. Nie tylko brak postępu reform, ale również sposób prowadzenia polityki przez władze oraz obawy wynikające z prochińskiej polityki rządzących już w 2014 roku doprowadziły do protestów społecznych (tzw. ruch słoneczników), w których większość stanowili młodzi ludzie. Tych 1,3 mln Tajwańczyków w wieku 20-24 lata, którzy nabyli prawa wyborcze i głosowali po raz pierwszy w 2016 roku, w zasadniczym względzie wpłynęło na obecny kształt tajwańskiej sceny politycznej. W wyborach 
w 2016 roku uprawnionych było 18,6 mln obywateli, a głosowało 12,4 miliona. To oznacza, że frekwencja wyniosła $66,27 \%$ i była najniższa w historii demokratycznych wyborów na Tajwanie ${ }^{70}$. Ocenia się, że w grupie najmłodszych wyborców frekwencja była znacznie wyższa od średniej. Gdyby do wyborów poszło chociaż 70\% młodych, dałoby to milion głosów spośród nowych wyborców. Tak koherentnej grupy nie powinien zbagatelizować żaden polityk. Jednak strategia polityczna Kuomintangu oszczędnie odwoływała się problemów interesujących ludzi młodych oraz angażowania ich w szeregach partii.

W badaniu nastrojów opinii publicznej Taiwan Indicators Survey Research, przeprowadzonym w maju 2016 roku, a więc już po zaprzysiężeniu nowej pani prezydent, wskazano, że w głównej mierze to młodzi Tajwańczycy przeciwstawiali się zjednoczeniu z Chinami - 81\% w grupie wiekowej 20-29 lat, a 72\% z nich popierała niepodległość Tajwanu. Ponadto wykazano, że młodzi i wykształceni Tajwańczycy sprzyjali, niezależnej względem władz w Pekinie, polityce administracji prezydent Tsai ${ }^{71}$.

\section{Kobiety w rządzie}

Obraz tajwańskiej sceny politycznej o rosnącym udziale kobiet, jaki uzewnętrzniły wybory powszechne ze stycznia 2016 roku, zaburzyły decyzje prezydent Tsai w sprawie desygnowania w większości męskiego składu rządu (Yuan Wykonawczy). Powołano zaledwie cztery panie na czterdziestu członków gabinetu (10\%): Cheng Li-chiun - Ministerstwo Kultury (Ministry of Culture), Chang Hsiao-yueh - Rada do Spraw Kontynentu (Mainland Affairs Council), Lin Mei-chu, minister bez teki i jednocześnie minister Komisji do Spraw Mongolskich i Tybetańskich (Mongolian and Tibetan Affairs Commission), Chan Ting-I w randze ministra - szefowa Narodowej

${ }^{70} 2016$ Presidential and Vice Presidential Election, Central Election Commission, Republic of China (Taiwan), www.cec.gov.tw/english/cms/pe/24835 (6.02.2017).

${ }^{71}$ Chiu Yan-ling, J. Chin, Majority reject unification: poll, „Taipei Times”, 31.05. 2016, www.taipeitimes.com/News/front/archives/2016/05/31/2003647521 (6.02.2017). 
Komisji Komunikacyjnej (National Communications Commission). Warto także wspomnieć o wyborze osoby transseksualnej - Tang Feng - na stanowisko ministra bez teki ${ }^{72}$. W dzienniku „Taipei Times” podkreślono idącą za tymi decyzjami personalnymi rządzących niekorzystną marginalizację pozycji kobiet w polityce, porównując, że w okresie rządów Kuomintangu (2008-2016) udział kobiet w rządzie wynosił 28,5\%. Decyzjom prezydent Tsai sprzeciwiły się działaczki organizacji feministycznych, organizując publiczny protest przed siedzibą Demokratycznej Partii Postępowej ${ }^{73}$. Media wskazywały słuszność wprowadzenia rozwiązań systemowych gwarantujących kwoty dla kobiet jako sposób wyjścia z takiego impasu w przyszłości. Dało się słyszeć głosy o podejmowaniu niewystarczających starań na rzecz pracy kobiet w polityce i rządzie, a także przewadze mężczyzn, gdy porównywać dotychczasowe doświadczenie i kontakty osobiste, które - jak wiadomo - w kręgach kultury konfucjańskiej odgrywają priorytetowe znaczenie ${ }^{74}$.

\section{Współczesny Tajwan w światowej czołówce działań na rzecz równości płci}

Badając aktywność kobiet w polityce na Tajwanie przez pryzmat zwycięstwa Tsai Ing-wen, warto sięgnąć szerzej do przekrojowych miar oddających rozwój społeczny na wyspie. Wskaźnik nierówności płci (Gender Inequality Index, GII) opracowany przez Program Narodów Zjednoczonych ds. Rozwoju odzwierciedla dyskryminację kobiet w trzech obszarach (ważonych pięcioma miarami): opieka zdrowotna (śmiertelność okołoporodowa, urodzenia wśród młodocianych); status społeczny (udział kobiet

${ }^{72}$ Executive Yuan Officials, Executive Yuan Republic of China (Taiwan), http:// english.ey.gov.tw/cp.aspx?n=DCD40847210A4163 (23.01.2017).

${ }^{73}$ E. Chang, Taipei Watcher: Don't expectgender revolution under Tsai admin: The new Cabinet consists of 40 people, of which 4 are women - and it's 2016, „Taipei Times”, 29.05.2016, www.taipeitimes.com/News/feat/archives/2016/05/29/2003647365/2 (23.01.2017).

${ }^{74}$ C. Sui, Taiwan, the place to be a woman in politics, BBC, 20.05.2016, www.bbc. com/news/world-asia-36309137 (6.02.2017). 
w parlamencie, populacja z wykształceniem średnim) i rynku pracy (aktywność zawodowa kobiet i mężczyzn) - wskaźnik ten przyjmuje wartości z przedziału $(0,1)$, gdzie 0 oznacza całkowitą równość pomiędzy płciami, a 1 to zupełny brak. W 2014 roku GII wyniósł na Tajwanie 0,052 $2^{75}$. W rankingu 155 przebadanych państw świata niższe wartości, świadczące o większej równości pomiędzy kobietami i mężczyznami, osiągnęły wówczas jedynie: Słowenia, Szwajcaria, Niemcy i Dania. Wysoki wynik Tajwanu dodatkowo potwierdza porównanie do sąsiednich państw o zbliżonych charakterystykach rozwojowych. Na 14. miejscu znalazł się Singapur z wynikiem GII 0,088; na 24. - Korea Południowa z wielkością GII równą 0,125, na 27. miejscu uplasowała się Japonia, gdzie GII osiągnął wartość 0,133. W sąsiednich Chinach GII wyniósł 0,191, co dało im 41. lokatę w świecie ${ }^{76}$. Dla porównania Polska zajęła 28. miejsce w rankingu, a wartość GII wyniosła $0,138^{77}$. Wysoki wskaźnik GII na Tajwanie obrazuje z jednej strony, że nawet tradycyjne i kulturowe przeszkody uniemożliwiające kobietom szeroką partycypację we współczesnym społeczeństwie można starać się zniwelować poprzez troskę o podnoszenie jakości życia, poziomu edukacji i popularyzację postulatów równości płci, ale przede wszystkim poprzez zmiany w prawodawstwie. $Z$ drugiej strony wskazuje, że proces równouprawnienia płci nie został jeszcze w pełni urzeczywistniony.

\section{Podsumowanie}

Wybory parlamentarne i prezydenckie w 2016 roku na Tajwanie spotkały się ze znacznym zainteresowaniem światowych mediów, ze względu na

${ }^{75}$ Gender at a Glance in R.O.C.: Version 2016, Executive Yuan, Republic of China, III 2016, Global Gender, www.globalgender.org/upload/download/version_2016. pdf (12.02.2017).

${ }^{76}$ Ibidem, s. 1.

${ }^{77}$ Human Development Report 2015: Work for human development: Briefing note for countries on the 2015 Human Development Report: Poland, United Nations Development Program, http://hdr.undp.org/sites/all/themes/hdr_theme/country-notes/ POL.pdf (22.02.2017). 
zwycięstwo kobiet, w gronie których Tsai Ing-wen zajęła najwyższe stanowisko - prezydenta Republiki Chińskiej. Takie ujęcie problemu nie oddaje jednak w pełni sytuacji na tajwańskiej scenie politycznej. Mylnie można na tej podstawie wnioskować zarówno o fenomenie odrzucenia tradycyjnych konfucjańskich norm społecznych z nadrzędną rolą przypisywaną mężczyznom, jak i o ewolucji systemu społecznego poprzez zniwelowanie nierówności płci. Prezydent Tsai nie powinna być odbierana jako unikatowy przykład równouprawnienia kobiet w polityce w dziejach demokratyzacji na Tajwanie. Jej karierę poprzedziły sukcesy przynajmniej trzech kobiet zaangażowanych w politykę: wiceprezydent Anette Lu, burmistrz Chen Chu oraz szefowej KMT Hung Hsiu-chu. Wybór na stanowisko wynikał także ze specyfiki lokalnej sceny politycznej - rywalizacji pomiędzy dwiema partiami politycznymi KMT i DPP, co wiązało się przede wszystkim z akceptacją przez Tajwańczyków dotychczasowych wyników polityki tych ugrupowań oraz z obawami co do potencjalnych zagrożeń. Pojawienie się znacznej liczby młodych wyborców w 2016 roku wzmocniło proces krytyki i odrzucania tego, co zastałe i nienowoczesne, bo wiążące się z polityką wdrażaną przez starsze generacje. Zwiększenie udziału kobiet w parlamencie powinno być upatrywane także jako konsekwencja zmian w systemie wyborczym, gwarantującym kwoty dla kobiet. Zmiany w ustawodawstwie, będące konsekwencją procesu demokratyzacji Tajwanu, nie byłyby wreszcie możliwe bez wcześniejszych przeobrażeń w sferze społecznej i gospodarczej, a także otwartości na wpływy z Zachodu. Aktywność polityczna kobiet stała się częścią tych przemian. W tym zakresie ważną rolę odegrały ugrupowania feministyczne, których osiągnięcia nie powinny być marginalizowane. Jeżeli zaś chodzi o wyjątkowość przypadku udziału kobiet w polityce na Tajwanie, to pozostaje podkreślić, że to właśnie na jego obszarze obowiązuje konstytucja Republiki Chińskiej, która, choć w zmienionej i dostosowanej do wymogów współczesności formie, od dawna zawiera odwołania do równouprawnienia kobiet, a te pozostają wciąż unikatowe w skali Azji. 